\title{
Assessment of Fusarium pseudograminearum and F. culmorum Biomass in Seedlings of Potential Host Cereal Species
}

Noel L. Knight ${ }^{\dagger}$ and Mark W. Sutherland, Centre for Crop Health, Faculty of Health, Engineering and Sciences, University of Southern Queensland, Toowoomba, Queensland, 4350, Australia

\begin{abstract}
Fusarium crown rot is a major disease of wheat and barley worldwide, with the most frequently isolated causal agents being Fusarium pseudograminearum and $F$. culmorum. This study has successfully designed a quantitative polymerase chain reaction assay that is specific for $F$. culmorum, which has been used in conjunction with a previously established F. pseudograminearum-specific assay to compare the location and extent of infection by each fungus across a range of potential hosts, including six winter and three summer cereal species. All common winter cereals, excluding oat, demonstrated a similar range of visual and fungal biomass results when inoculated with either $F$. pseudograminearum or

F. culmorum. Oat exhibited the lowest visual disease ratings and fungal biomass values of the winter cereals, while the sorghum, maize, and rice cultivars returned the lowest values overall. The ranking of host species according to visual discoloration was strongly correlated for both pathogens. Visual reactions to $F$. pseudograminearum were greater than those caused by F. culmorum in all potential hosts trialed; however, fungal biomass results only indicated this trend for barley. These results demonstrate significant variation in the ability of these pathogens to colonize the range of cereal species examined and also suggest differences between the pathogens in their patterns of host colonization.
\end{abstract}

Fusarium crown rot has been recorded in all areas where wheat is grown, including Australia (Backhouse et al. 2004; Burgess et al. 1975), Europe (Balmas 1994; Cassini 1981; Rossi et al. 1995), North America (particularly the Pacific Northwest region of the United States) (Cook 1968; Moya-Elizondo et al. 2011; Smiley and Patterson 1996), South America (Moya-Elizondo et al. 2015), South Africa (Klaasen et al. 1991; Van Wyk et al. 1987), West Asia (Saremi et al. 2007; Tunali et al. 2008), and North Africa (Gargouri et al. 2001; Mergoum et al. 2000). In Australia, crown rot results in annual estimated losses of $\$ 79$ million in spring wheat and \$18 million in barley (Murray and Brennan 2009a,b). In the Pacific Northwest of the United States, crown rot has been estimated to cause a mean yield reduction of $9.5 \%$, reaching as high as $35 \%$, in commercial fields (Smiley et al. 2005).

Fusarium pseudograminearum (O'Donnell \& T. Aoki, $=F$. graminearum group $\mathrm{I},=$ Gibberella coronicola) and $F$. culmorum (W. G. Sm.) Sacc. are the most common causal agents of crown rot, with environmental conditions affecting the prevalence of each species within regions (Backhouse et al. 2004; Moya-Elizondo et al. 2011; Smiley and Patterson 1996; Tunali et al. 2008). In Queensland and New South Wales, Australia, crown rot is predominantly caused by $F$. pseudograminearum (Backhouse et al. 2004; Burgess et al. 1975; Scott et al. 2004). F. pseudograminearum is also the most common species associated with crown rot in Victoria and South Australia; however, F. culmorum is also frequently isolated in the high-rainfall areas of these states, where $F$. culmorum can be the dominant pathogen in some fields (Backhouse and Burgess 2002; Backhouse et al. 2004). Cropping systems and rotations have also been reported to affect the occurrence of these two pathogens in the Pacific Northwest of the United States (Smiley et al. 2016).

Both Fusarium spp. can be associated with the Fusarium crown rot "complex" but have been described as affecting wheat hosts differently. Studies by Liddell (1985) indicated that $F$. pseudograminearum caused severe aboveground symptoms earlier than F. culmorum, colonizing the subcrown internode, leaf sheaths, and culm bases and causing marked necrosis. F. culmorum caused less severe necrosis of these

${ }^{\dagger}$ Corresponding author: N. L. Knight; E-mail: noel.knight@outlook.com

Accepted for publication 11 July 2017.

() 2017 The American Phytopathological Society tissues and caused a cortical rot of the crown roots. Dyer et al. (2009) also indicated that the disease severity index of wheat culms was lower for $F$. culmorum-inoculated plants than $F$. pseudograminearum; however, $F$. culmorum caused greater stand losses (Dyer et al. 2009; Malalasekera and Colhoun 1968). Examination of these pathogens has also included DNA analyses of field soils prior to planting (Hollaway et al. 2013), which indicated that levels of $F$. pseudograminearum and F. culmorum DNA were positively correlated with crown rot expression (visual stem browning and whitehead expression) in durum wheat, spring wheat, and barley.

$F$. pseudograminearum and $F$. culmorum have been isolated from all major winter cereals. Spring wheat (Triticum aestivum L.), durum wheat (T. turgidum L. var. durum), barley (Hordeum vulgare L.), and triticale ( $\times$ Triticosecale Wittmack) are symptomatic primary hosts for F. pseudograminearum (Purss 1966; Quazi et al. 2009; Simmonds 1941). Cereal oat (Avena sativa L.) and the grass weed wild oat (A. fatua L.) become infected by $F$. pseudograminearum but are considered asymptomatic hosts that are likely to contribute to the maintenance of inoculum (Burgess et al. 2001; Nelson and Burgess 1994, 1995). F. pseudograminearum has also been isolated from many other grass genera, including Agropyron, Austrostipa, Avena, Bromus, Danthonia, Dicanthium, Hordeum, Panicum, Phalaris, and Zea (Bentley 2007; Burgess 1967; Purss 1969; Simmonds 1966). F. culmorum has a similarly wide range of host plants such as wheat, barley, oat, rye (Secale cereale L.), maize (Zea mays L.), sorghum (Sorghum bicolor L. Moench), and various grasses (Paterson et al. 2005). This broad host range, which includes grass weeds, allows these Fusarium spp. to survive in many environments and produce further inoculum even when host crops have been removed. This ability has major implications for cropping, particularly when planning crop rotations, weed control, and disease management.

Quantitative methods for reporting fungal biomass have been used in several studies to examine $F$. pseudograminearum (Hogg et al. 2007; Knight and Sutherland 2013; Knight et al. 2012) or F. culmorum (Leišová et al. 2006; Petrisko and Windes 2006) colonization of hosts; however, not comparatively in the same study. These investigations have indicated a strong correlation between visual disease ratings and fungal biomass in wheat and barley, along with host genotypic variation. Genotypic variation in seedling reaction to disease within wheat has been well documented for $F$. pseudograminearum (Knight et al. 2012; Percy et al. 2012; Wildermuth and McNamara 1994) and F. culmorum (Dyer et al. 2009; Grey and Mathre 1988); however, a comparison between a 
large range of potential host species has not been performed for either pathogen.

The first objective of this study was to develop a primer/probebased quantitative polymerase chain reaction (qPCR) assay for specifically detecting and quantifying $F$. culmorum in plant tissue. The assay was designed to require conditions similar to those described by Knight et al. (2012) for quantifying $F$. pseudograminearum, to allow a multiplex qPCR approach. Visual disease symptoms and fungal biomass of $F$. pseudograminearum and $F$. culmorum were then examined across a range of nine potential host species in seedling trials to investigate the response of different cereal species to infection by each pathogen and to compare the infection pathways and disease expression arising from the two pathogens in the same host species.

\section{Materials and Methods}

Fungal strains and inoculum preparation. Pathogen strains included the $F$. pseudograminearum isolate A03\#24, collected from Tara, Queensland, Australia (Malligan 2009), and F. culmorum isolate Fc08-35, collected from Inverleigh, Victoria, Australia in 2008 (supplied by the Department of Primary Industries, Victoria, Australia). A single conidium culture was grown and maintained on spezieller nährstoffarmer agar (Nirenberg 1976). Subcultures were grown on starch nitrate agar (Dodman and Reinke 1982) in the dark at $25^{\circ} \mathrm{C}$ for 14 days. Conidia were collected by flooding plates with $5 \mathrm{ml}$ of a $0.3 \%$ Tween- 20 solution before filtering through two layers of cheesecloth with high-purity water (MilliQ; Millipore, Billerica, MA) to a volume of $10 \mathrm{ml}$. The conidial suspension was quantified using a counting chamber (Weber and Sons, Lancing, United Kingdom) and diluted to a concentration of $10^{6}$ conidia $/ \mathrm{ml}$. The final suspension was stored for a maximum of 2 months at $-70^{\circ} \mathrm{C}$ before inoculation.

Cultivars, growth conditions, and inoculation. Fifteen cultivars representing nine cereal species were grown for inoculation tests. Seed of 'EGA Wylie' (T. aestivum), 'Livingston' ( $T$. aestivum), 'EGA Bellaroi' (T. turgidum L. var. durum), 'Jandaroi' (T. turgidum var. durum), 'Tilga' (Hordeum vulgare), 'Grout' (Hordeum vulgare), 'Hawkeye' ( $\times$ Triticosecale), and 'Quoll' (A. sativa) were sourced from the Australian Winter Cereals Collection; 'Berkshire' ( $\times$ Triticosecale), 'Rysun' (Secale cereale), and 'Vampire' (S. cereale) from the University of Sydney; 'MR Buster' (Sorghum bicolor) and 'PAC 606' (Z. mays) from Pacific Seeds; 'Sherpa' (Oryza sativa L.) from Ricegrowers Limited; and 'Taipan' (A. sativa) from Agri-Science Queensland. Each seed was planted in a 5-by-5-by-10-cm pot at a depth of $2.5 \mathrm{~cm}$ in Premium Hi-Retention growing medium (Power Blend, Narangba, Queensland, Australia). All seedlings were grown in an environmentally controlled glasshouse at 24 and $15^{\circ} \mathrm{C}$ (day and night, respectively) for 14 days.

Seedlings were inoculated 14 days after planting using a method modified from Mitter et al. (2006) and described by Knight et al. (2012). Potted seedlings were laid horizontally, each coleoptile was gently rubbed $0.5 \mathrm{~cm}$ behind the tip with a sterile toothpick, and $6 \mu \mathrm{l}$ of the $10^{6}$ conidia/ml inoculum was placed on this area. Control plants were treated with $6 \mu l$ of high-purity water. After inoculation, seedlings were placed in a growth chamber in the dark for
$48 \mathrm{~h}$ with 2 cycles of $25^{\circ} \mathrm{C}$ for $14 \mathrm{~h}$ followed by $15^{\circ} \mathrm{C}$ for $10 \mathrm{~h}$ at $100 \%$ relative humidity. After $48 \mathrm{~h}$, seedlings were placed upright in an environmentally controlled glasshouse and subsequently maintained at 24 and $15^{\circ} \mathrm{C}$ (day and night, respectively) for 21 days. Two independent replications of the experiment were conducted at different times. Each replicate consisted of five inoculated plants and two noninoculated control plants of each cultivar. Plants were positioned in a randomized block design after removal from the 48-h dark incubation. F. pseudograminearum and $F$. culmorum inoculations were in separate randomized blocks which were grown and inoculated simultaneously.

Disease assessment. Harvest of leaf sheaths and roots was performed at 21 days after inoculation (dai). Leaf sheath samples were collected as combined leaf sheath 1 to 4 of each individual plant. At harvest, each of the leaf sheaths was rated based on the percentage of brown discoloration of the entire leaf sheath (Wildermuth and McNamara 1994). Briefly, leaf sheaths were rated for disease on a 0 -to- 4 scale, where $0=$ no visible discoloration and $1=$ less than $25 \%, 2=25$ to $50 \%, 3=51$ to $75 \%$, and $4=$ greater than $75 \%$ discoloration. Visual discoloration was recorded as the average of the ratings of the four leaf sheaths from an individual plant. Noninfected control plants were used to distinguish disease symptoms from background pigmentation present in some of the cultivars tested. The upper $2-\mathrm{cm}$ portions of the primary roots were washed and collected for Tilga, Grout, Livingston, EGA Wylie, Jandaroi, and EGA Bellaroi. All harvested tissues were stored at $-70^{\circ} \mathrm{C}$ until lyophilization.

DNA extraction. Combined leaf sheaths 1 to 4 or the upper 2-cm portion of the primary roots of each individual plant were lyophilized, weighed, and ground with a TissueLyser (Qiagen, Doncaster, Victoria, Australia). Ground tissues were subsampled into 15- to 20mg samples for extraction. Genomic DNA was extracted using a Wizard Genomic DNA Purification Kit (Promega, Sydney, NSW, Australia) according to the manufacturer's recommended procedure. Samples were eluted into $100 \mu \mathrm{l}$ of autoclaved high-purity water and stored at $-20^{\circ} \mathrm{C}$ until required.

F. culmorum qPCR assay validation. A species-specific primer/ probe combination (Table 1) was designed for F. culmorum from the GenBank accession AY880844.1 (Klemsdal and Elen 2006; Schilling et al. 1996) using Primer3 software (Rozen and Skaletsky 2000). A dual-labeled probe was obtained from Biosearch Technologies (Novato, CA). Primer and probe sequences were assessed by a BLAST (https:// blast.ncbi.nlm.nih.gov/Blast.cgi) search of the GenBank nucleic acid database using the Others (nr etc.) database: Nucleotide Collection (nr/nt). DNA of each cereal cultivar and a range of Fusarium spp. (Table 2) was used to assess the specificity of the qPCR assay. Five 10-fold serial dilutions of pure genomic F. culmorum DNA and Triticum DNA were run in triplicate to assess the multiplex assay. Intra- and interassay variation was assessed using a single DNA sample extracted from an F. culmorum-inoculated plant sample.

Dual-labeled probe PCR conditions. F. pseudograminearum and Triticum primer/probe sets were used as described by Knight et al. (2012) and the F. culmorum and Triticum primer/probe sets were amplified under the same qPCR conditions. Reactions were performed in $20-\mu l$ volumes containing autoclaved high-purity

Table 1. Primer pairs (forward $=\mathrm{F}$ and reverse $=\mathrm{R}$ ) and dual-labeled probes $(\mathrm{P})$ developed for specific quantification of Fusarium pseudograminearum, F. culmorum, or Triticum sp. DNA

\begin{tabular}{|c|c|c|c|c|}
\hline Primer/probe & Sequence $\left(5^{\prime} \rightarrow 3^{\prime}\right)$ & Target & Product (bp) & GenBank accession \\
\hline Fp_TEF $1 \alpha 0.2 \mathrm{~F}^{\mathrm{z}}$ & ATCATTCGAATCGCTCGACG & F. pseudograminearum & & \\
\hline Fp_TEF $1 \alpha 0.2 R^{z}$ & AAAAATTACGACAAAGCCGTAAAAA & F. pseudograminearum & 82 & \\
\hline Fp_TEF $1 \alpha 0.2 \mathrm{P}^{\mathrm{z}}$ & ACTCGACACGCGCCTGTTACCC & F. pseudograminearum & $\ldots$ & DQ382162 \\
\hline Wh_TEFG.5F $\mathrm{F}^{\mathrm{z}}$ & TCCGTGAAGGATTGAGGAA & Triticum sp. & $\ldots$ & $\ldots$ \\
\hline Wh_TEFG.5R $\mathrm{R}^{\mathrm{z}}$ & GTCCTCTTCTAGAGTTCAAGTCACC & Triticum sp. & 120 & \\
\hline Wh_TEFG.5Pz & TGGCCCACGACTCCTGGAACCTATA & Triticum sp. & $\ldots$ & DQ247872 \\
\hline Fc_K13B-P_F & ATGACCGAAGACTCGGAGAA & F. culmorum & $\ldots$ & $\ldots$ \\
\hline Fc_K13B-P_R & ACCTTGTGCTGAGCTCGTCT & F. culmorum & 112 & \\
\hline Fc_K13B-P_P & CGAACTCGCAGGCAGAAGCG & F. culmorum & $\ldots$ & AY880844.1 \\
\hline
\end{tabular}

${ }^{\mathrm{z}}$ Primer/probe sequences published in Knight et al. (2012). 
water, $0.5 \mathrm{U}$ of Immolase DNA polymerase, $1 \times$ Immobuffer, $2.5 \mathrm{mM} \mathrm{MgCl} 2,100 \mu \mathrm{M}$ dNTP, $150 \mathrm{nM} F$. pseudograminearum or F. culmorum CAL Fluor Gold-labeled probe, $150 \mathrm{nM}$ Triticum FAM-labeled probe, $0.25 \mu \mathrm{M}$ forward and reverse primers for $F$. pseudograminearum or $F$. culmorum and Triticum spp., and $5 \mu l$ of DNA template.

Table 2. Fusarium and cereal species assessed using the Fusarium culmorum and Triticum sp. primer/probe sets

\begin{tabular}{|c|c|c|c|}
\hline Species & $\begin{array}{c}\text { Isolates } \\
\text { tested }(n)\end{array}$ & $\begin{array}{c}\text { F. culmorum } \\
\text { primers }^{w}\end{array}$ & $\begin{array}{c}\text { Triticum } \\
\text { primers }^{\mathrm{w}}\end{array}$ \\
\hline F. compactum $^{\mathrm{x}}$ & 2 & - & - \\
\hline F. crookwellense ${ }^{\mathrm{x}}$ & 2 & - & - \\
\hline F. culmorum $^{\mathrm{y}}$ & 9 & + & - \\
\hline F. equiseti ${ }^{\mathrm{x}}$ & 2 & - & - \\
\hline$F \cdot p o a e^{\mathrm{x}}$ & 2 & - & - \\
\hline F. proliferatum ${ }^{\mathrm{x}}$ & 2 & - & - \\
\hline F. $\operatorname{scirpi}^{\mathrm{x}}$ & 2 & - & - \\
\hline F. semitectum ${ }^{\mathrm{x}}$ & 2 & - & - \\
\hline F. pseudograminearum ${ }^{\mathrm{z}}$ & 17 & - & - \\
\hline F. graminearum $^{\mathrm{x}}$ & 5 & - & - \\
\hline Triticum aestivum & 5 & - & + \\
\hline Triticum turgidum durum & 2 & - & + \\
\hline Hordeum vulgare & 2 & - & - \\
\hline Avena sativa & 2 & - & - \\
\hline$\times$ Triticosecale & 2 & - & + \\
\hline Secale cereale & 2 & - & + \\
\hline Sorghum bicolor & 1 & - & - \\
\hline Zea mays & 1 & - & - \\
\hline Oryza sativa & 1 & - & - \\
\hline
\end{tabular}

${ }^{\mathrm{w}}$ Symbols + and - indicate a positive and negative polymerase chain reaction result, respectively, for the primer/probe set. All genotypes within each species gave similar responses.

${ }^{x}$ Fusarium spp. supplied by the University of Sydney, New South Wales, Australia.

y F. culmorum included two isolates supplied by the University of Sydney; two isolates from the Leslie Research Centre, Queensland Department of Agriculture and Fisheries, Queensland, Australia; and five isolates from the Department of Primary Industries, Victoria, Australia.

${ }^{\mathrm{z}}$ F. pseudograminearum included five isolates supplied by the University of Sydney; nine isolates from the Leslie Research Centre, Queensland Department of Agriculture and Fisheries; and three isolates from the Department of Primary Industries, Victoria.
Multiplex real-time qPCR was performed using 100- $\mu$ l tubes in a Rotor-Gene 6000 (Corbett Life Science, Sydney, Australia). Thermal cycling conditions consisted of $10 \mathrm{~min}$ at $95^{\circ} \mathrm{C}$ followed by 35 cycles of $95^{\circ} \mathrm{C}$ for $15 \mathrm{~s}$ and $64^{\circ} \mathrm{C}$ for $1 \mathrm{~min}$. The Rotor-Gene 6000 series software collected fluorescence data for both reporter dyes every $0.15 \mathrm{~s}$ from each tube.

PCR controls in every assay included no-template controls and genomic DNA standards (positive or negative) for $F$. pseudograminearum, F. culmorum, and Triticum spp. Each PCR included a 10-fold serial dilution series of pure genomic Triticum DNA and $F$. pseudograminearum DNA or $F$. culmorum DNA run in duplicate. DNA concentrations of standards were determined by measuring optical density at $260 \mathrm{~nm}$ using a nanophotometer (Implen, Munich, Germany). Standard dilution series included four 10-fold serial dilutions for $F$. pseudograminearum and F. culmorum DNA (10 ng to $1 \mathrm{pg}$ ) and three 10-fold serial dilutions for Triticum DNA (100 ng to $100 \mathrm{pg}$ ). Standard curves were generated by plotting known DNA quantities against the threshold cycle calculated by the Rotor-Gene 6000 software in order to produce a regression equation in each assay. Normalization of qPCR results was performed by dividing the Fusarium DNA quantity by the weight of extracted tissue (nanograms of Fusarium DNA per dry weight grams of host tissue) to produce the values used to describe fungal biomass.

Statistics. For analysis, the ordinal visual discoloration ratings from the four leaf sheaths of an individual plant were averaged. Spearman's nonparametric rank correlation coefficient was used to examine interrelationships between visual discoloration ratings and Fusarium biomass values. Visual discoloration ratings were converted to ranks using the Kruskal-Wallis nonparametric procedure. Fusarium biomass values were fourth-root transformed. Visual discoloration ranks and Fusarium biomass values were analyzed separately for each Fusarium sp. using a nonparametric analysis of variance, with cultivar and replicate as fixed and random effects, respectively. Variance parameters were estimated using restricted maximum-likelihood estimation (Patterson and Thompson 1971). Multiple comparisons were performed using Fisher's protected least significant difference test when there was a significant cultivar effect.

Visual discoloration ratings and Fusarium biomass values for both Fusarium spp. were analyzed together, with cultivar and replicate block fitted as random effects. An unstructured variance model was applied to the genetic variance, allowing for the estimation of a genetic variance for and genetic covariance between each Fusarium sp. for the visual discoloration ratings and Fusarium biomass values. Estimates of genetic

Table 3. Comparisons of 15 cereal cultivars using leaf sheath visual discoloration (VisD) ratings and fungal biomass (nanograms of DNA per gram of extracted tissue) after inoculation with Fusarium pseudograminearum or F. culmorum $^{\mathrm{x}}$

\begin{tabular}{|c|c|c|c|c|c|}
\hline \multirow[b]{2}{*}{ Cultivar } & \multirow[b]{2}{*}{ Species } & \multicolumn{2}{|c|}{ F.pseudograminearum } & \multicolumn{2}{|c|}{ F. culmorum } \\
\hline & & VisD $^{y}$ & Biomass $(\mathbf{n g} / \mathbf{g})^{\mathbf{z}}$ & VisD $^{y}$ & Biomass $(\mathrm{ng} / \mathrm{g})^{\mathrm{z}}$ \\
\hline Taipan & Avena sativa & $0.1 \mathrm{~d}$ & $18 \mathrm{fe}$ & $0.2 \mathrm{efg}$ & $24 \mathrm{c}$ \\
\hline PAC 606 & Zea mays & $0.1 \mathrm{~d}$ & $0 \mathrm{~h}$ & $0.1 \mathrm{fg}$ & $0 \mathrm{e}$ \\
\hline MR Buster & Sorghum bicolor & $0.1 \mathrm{~d}$ & $5 \mathrm{~g}$ & $0.0 \mathrm{~g}$ & $2 \mathrm{~d}$ \\
\hline Sherpa & Oryza sativa & $0.2 \mathrm{~d}$ & $12 \mathrm{f}$ & $0.1 \mathrm{fg}$ & $26 \mathrm{c}$ \\
\hline Quoll & Avena sativa & $0.3 \mathrm{~d}$ & 56 ed & $0.2 \mathrm{def}$ & $40 \mathrm{c}$ \\
\hline Rysun & Secale cereale & $1.2 \mathrm{c}$ & $63 \mathrm{e}$ & $0.3 \mathrm{de}$ & $652 \mathrm{a}$ \\
\hline Vampire & Secale cereale & $1.3 \mathrm{c}$ & $764 \mathrm{cb}$ & $0.5 \mathrm{~cd}$ & $765 \mathrm{a}$ \\
\hline Berkshire & $\times$ Triticosecale & $1.6 \mathrm{bc}$ & $123 \mathrm{~d}$ & $0.5 \mathrm{~cd}$ & $163 \mathrm{~b}$ \\
\hline EGA Wylie & Triticum aestivum & $2.2 \mathrm{ab}$ & $600 \mathrm{cb}$ & $0.8 \mathrm{abc}$ & $378 \mathrm{a}$ \\
\hline Tilga & Hordeum vulgare & $2.3 \mathrm{ab}$ & $583 \mathrm{~b}$ & $0.7 \mathrm{abc}$ & $91 \mathrm{~b}$ \\
\hline EGA Bellaroi & Triticum turgidum var. durum & $2.3 \mathrm{ab}$ & $571 \mathrm{cb}$ & $0.9 \mathrm{a}$ & $466 \mathrm{a}$ \\
\hline Jandaroi & Triticum turgidum var. durum & $2.4 \mathrm{ab}$ & $411 \mathrm{cb}$ & $0.8 \mathrm{ab}$ & $467 \mathrm{a}$ \\
\hline Livingston & Triticum aestivum & $2.5 \mathrm{ab}$ & $502 \mathrm{cb}$ & $1.1 \mathrm{a}$ & $465 \mathrm{a}$ \\
\hline Hawkeye & $\times$ Triticosecale & $2.5 \mathrm{ab}$ & $471 \mathrm{c}$ & $0.8 \mathrm{abc}$ & $608 \mathrm{a}$ \\
\hline Grout & Hordeum vulgare & $3.0 \mathrm{a}$ & $1,797 \mathrm{a}$ & $0.6 \mathrm{bc}$ & $122 \mathrm{~b}$ \\
\hline
\end{tabular}

${ }^{\mathrm{x}}$ Mean separations were calculated on transformed VisD rating and fungal biomass values using Fisher's protected least significant difference test $(P>0.05)$. In each column, cultivar scores with the same letter are not significantly different $(n=10,0.05$ significance level). Cultivars are ordered by their $F$. pseudograminearum visual discoloration rating.

${ }^{\mathrm{y}}$ Mean of individual rating scores for first four leaf sheaths.

${ }^{\mathrm{z}}$ Fungal biomass in combined tissues of the first four leaf sheaths. 
variance and genetic covariance were then used to quantify the genetic correlations between species and disease measurements. Estimates of cultivar effects were generated from this model as empirical best linear unbiased predictions.

All analyses were performed in Genstat (18th edition; VSN International Limited, Hemel Hempstead, UK). All tests used a significance level of 0.05 . Mean separations, calculated by least significant difference values, were produced from transformed visual discoloration rating and Fusarium biomass values.

\section{Results}

F. culmorum qPCR assay validation. The $F$. culmorum primer/ probe set derived from GenBank accession AY880844.1 specifically amplified DNA of $F$. culmorum isolates only (Table 2). The $F$. culmorum primer/probe set and Triticum primer/probe set were compatible during multiplex qPCR assessment, utilizing the PCR conditions reported by Knight et al. (2012). F. culmorum DNA was quantifiable from 0.001 to $100 \mathrm{ng}$ and wheat was quantifiable from 0.05 to $500 \mathrm{ng}$. The linear regression correlations between the threshold cycle and known DNA quantities were strong for both $F$. culmorum $\left(R^{2}>0.99, y=-3.4 x+22.96, E=0.96\right)$ and Triticum $\left(R^{2}>0.99\right.$, $y=-3.2 x+30.0, E=1.03)$. The respective mean values and coefficient of variation $(\mathrm{CV})$ for the intra-assy $(n=10)$ and inter-assay $(n=8)$ variability of the threshold cycle of a single sample containing both F. culmorum and Triticum DNA were 23.6/23.93 F. culmorum/Triticum (CV 1.8/1.8\%) and 23.2/22.7 F. culmorum/Triticum (CV 4.9/3.6\%), respectively. Restricted maximum-likelihood estimation analysis of the two independent replications of this experiment indicated that the data from both could be pooled to form a single data set in which there were 10 data points per variable for each individual host cultivar-pathogen interaction.

Visual discoloration of host cultivars. Visual discoloration of each host cultivar due to $F$. pseudograminearum or $F$. culmorum at 21 dai indicated a broad range of responses (Table 3). In general, visual discoloration was significantly less in Sherpa rice, PAC 606

Table 4. Comparisons of barley, spring wheat, and durum wheat cultivars using Fusarium pseudograminearum and $F$. culmorum biomass (nanograms of DNA per gram of extracted tissue) in primary root tissues ${ }^{z}$

\begin{tabular}{lcc}
\hline & \multicolumn{2}{c}{ Biomass (ng/g) } \\
\cline { 2 - 3 } Cultivar & $\boldsymbol{F}$.pseudograminearum & $\boldsymbol{F}$. culmorum \\
\hline Tilga & $25 \mathrm{c}$ & $49 \mathrm{a}$ \\
EGA Wylie & $52 \mathrm{bc}$ & $41 \mathrm{a}$ \\
Grout & $85 \mathrm{abc}$ & $120 \mathrm{a}$ \\
Jandaroi & $104 \mathrm{ab}$ & $111 \mathrm{a}$ \\
EGA Bellaroi & $123 \mathrm{ab}$ & $126 \mathrm{a}$ \\
Livingston & $120 \mathrm{a}$ & $122 \mathrm{a}$ \\
\hline
\end{tabular}

${ }^{\mathrm{z}}$ In each column, cultivar scores with the same letter are not significantly different $(n=10,0.05$ significance level). Mean separations were calculated on transformed fungal biomass values using Fisher's protected least significant difference test $(P>0.05)$. maize, MR Buster sorghum, and Taipan and Quoll oat than the other cultivars and species. The genetic correlation for visual discoloration between $F$. pseudograminearum and $F$. culmorum was 0.98 , where the genetic correlation indicates the agreement in cultivar rankings between the two Fusarium spp.

Fusarium biomass in leaf sheath tissues. $F$. pseudograminearum and $F$. culmorum biomass encompassed a wide range of values across the host species (Table 3). The maize (with no detectable Fusarium DNA) and sorghum cultivars contained the least Fusarium biomass in their leaf sheath tissues, followed by Sherpa rice. Taipan and Quoll oat also reported low levels of Fusarium biomass compared with the other winter cereals. The genetic correlation for Fusarium biomass between $F$. pseudograminearum and $F$. culmorum was 0.76 , where the genetic correlation indicates the agreement in cultivar rankings between the two Fusarium spp. tested.

Correlation of visual discoloration and Fusarium biomass in leaf sheath tissues. A significant association was detected between visual discoloration and Fusarium biomass for both $F$. pseudograminearum $(\rho=0.72 ; P<0.001)$ and $F$. culmorum $(\rho=0.69 ; P<0.001)$.

$F$. pseudograminearum and $F$. culmorum biomass in root tissues. $F$. pseudograminearum and $F$. culmorum DNA was detected in root samples from each of the six cultivars tested (Table 4). Tilga barley had significantly less $F$. pseudograminearum DNA than Jandaroi and EGA Bellaroi durum wheat and Livingston spring wheat. In contrast, there were no significant differences across the cultivars for F. culmorum biomass.

Comparison of $F$. pseudograminearum and $F$. culmorum visual discoloration levels. Visual discoloration ratings due to $F$. pseudograminearum were significantly greater than those due to $F$. culmorum in the majority of cereal cultivars tested (Table 5). Only Vampire rye, Taipan and Quoll oat, PAC 606 maize, and Sherpa rice did not differ significantly for discoloration caused by either pathogen. The same values are presented in Table 5 as in Tables 3 and 4; however, in Table 5, these have been analyzed to compare the two Fusarium spp. on each cultivar. Examination of ratings separated into leaf sheaths 1, 2, 3, and 4 (Table 6) indicated differences between Fusarium spp. similar to those described using combined ratings of discoloration. Discoloration due to $F$. culmorum appeared at comparatively low levels in leaf sheath 2 , was at low levels or absent in leaf sheath 3 , and was absent in leaf sheath 4 . In contrast, visual discoloration was apparent in all four leaf sheaths following $F$. pseudograminearum infection in all but the five least susceptible cultivars.

Comparison of $F$. pseudograminearum and $F$. culmorum biomass. The leaf sheaths of Tilga and Grout barley indicated significantly higher levels of $F$. pseudograminearum DNA than $F$. culmorum DNA (Table 5). In contrast, Rysun rye contained significantly more $F$. culmorum DNA than $F$. pseudograminearum DNA. No other cultivars exhibited significantly different levels of pathogen DNA. No significant differences in pathogen DNA were observed in the roots of the spring wheat, durum wheat, and barley cultivars examined (Table 5).

\section{Discussion}

This study presents a novel qPCR assay for F. culmorum, based on specific sequences reported by Schilling et al. (1996) and Klemsdal

Table 5. Comparisons of Fusarium pseudograminearum and F. culmorum visual discoloration ratings and biomass (nanograms of DNA per gram of extracted tissue) in leaf sheath (LS; one to four) tissues and primary root tissues of 15 cereal cultivars ${ }^{\mathrm{z}}$

\begin{tabular}{|c|c|c|c|c|c|c|c|c|c|c|c|c|c|c|c|}
\hline Comparisons & Grout & Tilga & Hawkeye & Berkshire & Livingston & $\begin{array}{c}\text { EGA } \\
\text { Wylie }\end{array}$ & Jandaroi & $\begin{array}{c}\text { EGA } \\
\text { Bellaroi }\end{array}$ & Vampire & Rysun & Quoll & Taipan & Sherpa & $\begin{array}{c}\text { MR } \\
\text { Buster }\end{array}$ & PAC 606 \\
\hline \multicolumn{16}{|l|}{ Visual discoloration } \\
\hline F. pseudograminearum & $3.0 \mathrm{a}$ & $2.3 \mathrm{a}$ & $2.5 \mathrm{a}$ & $1.6 \mathrm{a}$ & $2.5 \mathrm{a}$ & $2.2 \mathrm{a}$ & $2.4 \mathrm{a}$ & $2.3 \mathrm{a}$ & $1.3 \mathrm{a}$ & $1.2 \mathrm{a}$ & $0.3 \mathrm{a}$ & $0.1 \mathrm{a}$ & $0.2 \mathrm{a}$ & $0.1 \mathrm{a}$ & $0.1 \mathrm{a}$ \\
\hline F. culmorum & $0.6 \mathrm{~b}$ & $0.7 \mathrm{~b}$ & $0.8 \mathrm{~b}$ & $0.5 \mathrm{~b}$ & $1.1 \mathrm{~b}$ & $0.8 \mathrm{~b}$ & $0.8 \mathrm{~b}$ & $0.9 \mathrm{~b}$ & $0.5 \mathrm{a}$ & $0.3 \mathrm{~b}$ & $0.2 \mathrm{a}$ & $0.2 \mathrm{a}$ & $0.1 \mathrm{a}$ & $0.0 \mathrm{~b}$ & $0.1 \mathrm{a}$ \\
\hline \multicolumn{16}{|l|}{ DNA in LS (ng/g) } \\
\hline F.pseudograminearum & $1,797 \mathrm{a}$ & $583 \mathrm{a}$ & $471 \mathrm{a}$ & $123 \mathrm{a}$ & $502 \mathrm{a}$ & $600 \mathrm{a}$ & $411 \mathrm{a}$ & $571 \mathrm{a}$ & $764 \mathrm{a}$ & $63 \mathrm{a}$ & 56 a & $18 \mathrm{a}$ & $12 \mathrm{a}$ & $5 \mathrm{a}$ & $0 \mathrm{a}$ \\
\hline F. culmorum & $122 \mathrm{~b}$ & $91 \mathrm{~b}$ & $608 \mathrm{a}$ & $163 \mathrm{a}$ & $465 \mathrm{a}$ & $378 \mathrm{a}$ & $467 \mathrm{a}$ & $466 \mathrm{a}$ & $765 \mathrm{a}$ & $652 \mathrm{~b}$ & $40 \mathrm{a}$ & $24 \mathrm{a}$ & $26 \mathrm{a}$ & $2 \mathrm{a}$ & $0 \mathrm{a}$ \\
\hline \multicolumn{16}{|l|}{ DNA in roots $(\mathrm{ng} / \mathrm{g})$} \\
\hline F. pseudograminearum & $85 \mathrm{a}$ & $25 \mathrm{a}$ & $\ldots$ & $\ldots$ & $120 \mathrm{a}$ & $52 \mathrm{a}$ & $104 \mathrm{a}$ & $123 \mathrm{a}$ & $\ldots$ & $\ldots$ & $\ldots$ & $\ldots$ & $\ldots$ & $\ldots$ & $\ldots$ \\
\hline F. culmorum & $120 \mathrm{a}$ & $49 \mathrm{a}$ & $\ldots$ & $\ldots$ & $122 \mathrm{a}$ & $41 \mathrm{a}$ & $111 \mathrm{a}$ & $126 \mathrm{a}$ & $\ldots$ & $\ldots$ & $\ldots$ & $\ldots$ & $\ldots$ & $\ldots$ & $\ldots$ \\
\hline
\end{tabular}

${ }^{\mathrm{z}}$ In each column, cultivar scores with the same letter are not significantly different for their reaction to $F$. pseudograminearum and $F$. culmorum ( $n=10,0.05$ significance level). Mean separations were calculated on transformed visual discoloration rating and fungal biomass values using Fisher's protected least significant difference test $(P>0.05)$. 
and Elen (2006). This assay has been used along with a previously reported $F$. pseudograminearum qPCR assay (Knight et al. 2012) to compare quantities of pathogen biomass and visual symptoms of infection across a range of potential host species. To our knowledge, this is the first comparative description of crown rot development across a broad range of cereal species and the results provide important information on the relationship between the level of fungal infection and the expression of disease symptoms for the two most prevalent crown rot pathogens of cereals worldwide.

This is also the first direct comparison of $F$. pseudograminearumand $F$. culmorum-inoculated plants using qPCR, and there is potential to utilize these assays to assess diseased plants in a range of situations, including glasshouse and field trials. This method adds a level of specificity which has not been available in previous reports based on primers amplifying a tri5 gene, which were unable to distinguish between the presence of $F$. pseudograminearum, $F$. culmorum, or $F$. graminearum in the crown rot complex (Hogg et al. 2007; Strausbaugh et al. 2005). Use of the tri5 gene allows field samples with mixed colonization to have their total Fusarium biomass measured in a single reaction, which is important for regions where multiple Fusarium spp. contribute to crown rot symptoms (Hogg et al. 2007; Tunali et al. 2008). The species-specific primers described in this study now allow the relative contributions of individual Fusarium spp. to be determined in glasshouse and field samples.

Crown rot research in Australia is most frequently performed using $F$. pseudograminearum due to it being the prevalent crown rot pathogen (Backhouse et al. 2004; Burgess et al. 1975); however, some investigations in Australia and the United States have included F. culmorum (Dyer et al. 2009; Evans et al. 2010; Hollaway et al. 2013). Wheat reactions to $F$. culmorum or $F$. pseudograminearum result in a similar trend in disease reactions between cultivars (Wallwork et al. 2004), with overall levels of disease generally depending on isolate aggressiveness. The current study also indicated that visible disease reaction and fungal biomass rankings across the range of hosts showed a significant correlation for the two Fusarium spp. Although the host reactions to each pathogen follow similar trends, several distinctions have been reported. A comparison of $F$. pseudograminearum and $F$. culmorum in Montana using spring and durum wheat indicated that $F$. pseudograminearum caused greater crown rot disease scores and a greater reduction in yield than $F$. culmorum, whereas $F$. culmorum caused greater seedling blight (Dyer et al. 2009). The F. pseudograminearum isolate in this study caused significantly greater visual symptoms than the

Table 6. Comparisons of Fusarium pseudograminearum and $F$. culmorum visual discoloration ratings in leaf sheath (LS) $1,-2,-3$, and -4 tissues of 15 cereal cultivars ${ }^{\mathrm{z}}$

\begin{tabular}{|c|c|c|c|c|c|c|c|c|}
\hline \multirow[b]{2}{*}{ Cultivar } & \multicolumn{4}{|c|}{ F. pseudograminearum } & \multicolumn{4}{|c|}{ F. culmorum } \\
\hline & LS1 & LS2 & LS3 & LS4 & LS1 & LS2 & LS3 & LS4 \\
\hline Grout & $4.0 \mathrm{a}$ & $3.6 \mathrm{a}$ & $2.8 \mathrm{a}$ & $1.6 \mathrm{a}$ & $2.0 \mathrm{~b}$ & $0.4 \mathrm{~b}$ & $0.0 \mathrm{~b}$ & $0.0 \mathrm{~b}$ \\
\hline Tilga & $3.7 \mathrm{a}$ & $2.9 \mathrm{a}$ & $2.0 \mathrm{a}$ & $0.7 \mathrm{a}$ & $2.1 \mathrm{~b}$ & $0.7 \mathrm{~b}$ & $0.1 \mathrm{~b}$ & $0.0 \mathrm{~b}$ \\
\hline Hawkeye & $3.3 \mathrm{a}$ & $3.0 \mathrm{a}$ & $2.4 \mathrm{a}$ & $1.3 \mathrm{a}$ & $2.4 \mathrm{a}$ & $0.7 \mathrm{~b}$ & $0.0 \mathrm{~b}$ & $0.0 \mathrm{~b}$ \\
\hline Berkshire & $3.6 \mathrm{a}$ & $2.2 \mathrm{a}$ & $0.5 \mathrm{a}$ & $0.1 \mathrm{a}$ & $1.4 \mathrm{~b}$ & $0.6 \mathrm{~b}$ & $0.0 \mathrm{~b}$ & $0.0 \mathrm{a}$ \\
\hline Livingston & $3.6 \mathrm{a}$ & $3.1 \mathrm{a}$ & $2.2 \mathrm{a}$ & $0.9 \mathrm{a}$ & $2.9 \mathrm{a}$ & $1.3 \mathrm{~b}$ & $0.3 \mathrm{~b}$ & $0.0 \mathrm{~b}$ \\
\hline EGA Wylie & $3.5 \mathrm{a}$ & $3.0 \mathrm{a}$ & $1.7 \mathrm{a}$ & $0.4 \mathrm{a}$ & $2.4 \mathrm{~b}$ & $0.6 \mathrm{~b}$ & $0.0 \mathrm{~b}$ & $0.0 \mathrm{~b}$ \\
\hline Jandaroi & $3.9 \mathrm{a}$ & $3.0 \mathrm{a}$ & $1.9 \mathrm{a}$ & $0.8 \mathrm{a}$ & $2.4 \mathrm{~b}$ & $0.7 \mathrm{~b}$ & $0.0 \mathrm{~b}$ & $0.0 \mathrm{a}$ \\
\hline EGA Bellaroi & $3.7 \mathrm{a}$ & $3.1 \mathrm{a}$ & $1.7 \mathrm{a}$ & $0.8 \mathrm{a}$ & $2.7 \mathrm{~b}$ & $0.9 \mathrm{~b}$ & $0.1 \mathrm{~b}$ & $0.0 \mathrm{a}$ \\
\hline Vampire & $1.9 \mathrm{a}$ & $1.5 \mathrm{a}$ & $1.3 \mathrm{a}$ & $0.4 \mathrm{a}$ & $1.2 \mathrm{a}$ & $0.6 \mathrm{a}$ & $0.3 \mathrm{~b}$ & $0.0 \mathrm{a}$ \\
\hline Rysun & $1.8 \mathrm{a}$ & $1.5 \mathrm{a}$ & $1.0 \mathrm{a}$ & $0.6 \mathrm{a}$ & $1.1 \mathrm{a}$ & $0.1 \mathrm{~b}$ & $0.0 \mathrm{~b}$ & $0.0 \mathrm{a}$ \\
\hline Quoll & $0.8 \mathrm{a}$ & $0.2 \mathrm{a}$ & $0.0 \mathrm{a}$ & $0.0 \mathrm{a}$ & $0.8 \mathrm{a}$ & $0.0 \mathrm{a}$ & $0.0 \mathrm{a}$ & $0.0 \mathrm{a}$ \\
\hline Taipan & $0.3 \mathrm{a}$ & $0.0 \mathrm{a}$ & $0.0 \mathrm{a}$ & $0.0 \mathrm{a}$ & $0.6 \mathrm{a}$ & $0.0 \mathrm{a}$ & $0.0 \mathrm{a}$ & $0.0 \mathrm{a}$ \\
\hline Sherpa & $0.4 \mathrm{a}$ & $0.2 \mathrm{a}$ & $0.0 \mathrm{a}$ & $0.0 \mathrm{a}$ & $0.2 \mathrm{a}$ & $0.0 \mathrm{a}$ & $0.0 \mathrm{a}$ & $0.0 \mathrm{a}$ \\
\hline MR Buster & $0.5 \mathrm{a}$ & $0.0 \mathrm{a}$ & $0.0 \mathrm{a}$ & $0.0 \mathrm{a}$ & $0.0 \mathrm{~b}$ & $0.0 \mathrm{a}$ & $0.0 \mathrm{a}$ & $0.0 \mathrm{a}$ \\
\hline PAC 606 & $0.3 \mathrm{a}$ & $0.0 \mathrm{a}$ & $0.0 \mathrm{a}$ & $0.0 \mathrm{a}$ & $0.2 \mathrm{a}$ & $0.0 \mathrm{a}$ & $0.0 \mathrm{a}$ & $0.0 \mathrm{a}$ \\
\hline
\end{tabular}

${ }^{\mathrm{z}}$ For each leaf sheath in each cultivar, F. pseudograminearum and F. culmorum scores with the same letter are not significantly different $(n=10,0.05$ significance level). Mean separations were calculated on transformed visual discoloration rating values using Fisher's protected least significant difference test $(P>0.05)$.
F. culmorum isolate in the barley, spring wheat, durum wheat, triticale, and one rye cultivar; however, this only translated into significant differences in fungal biomass for the barley cultivars. Liddell (1985) also described an increased level of visual symptoms in wheat caused by $F$. pseudograminearum compared with $F$. culmorum; however, no pathogen biomass data were available. This may indicate that $F$. pseudograminearum hyphae colonize individual leaf sheaths to a greater extent and further into adjacent leaf sheaths, producing more visual symptoms, whereas $F$. culmorum produces a similar amount of hyphae which does not colonize leaf sheaths as far distant from the inoculation point or as far into adjacent leaf sheaths. Alternatively, host responses to $F$. pseudograminearum may produce higher levels of tissue discoloration than responses to an equivalent biomass of $F$. culmorum. The limitation of $F$. culmorum growth in barley compared with $F$. pseudograminearum indicates that some level of species specificity may exist, which could be investigated further using multiple isolates of these two Fusarium spp.

The common host species have had considerable research focus on their crown rot reactions. Genotypic variation (partial resistance) in host response to $F$. pseudograminearum infections has been described in spring wheat (Klein et al. 1989; Percy et al. 2012; Wallwork et al. 2004; Wildermuth and McNamara 1994) and barley ( $\mathrm{Li}$ et al. 2009; Nelson and Burgess 1994). In durum wheat cultivars, which are typically highly susceptible to crown rot, recent work to transfer resistance across from spring wheat is promising (Martin et al. 2013). Comparative assessment of multiple cereal species for crown rot disease reactions have been limited to date. Klein et al. (1989) reported the incidence of basal browning across 13 spring wheat cultivars, a single cultivar of durum wheat, barley, and triticale in northern New South Wales. Nelson and Burgess (1994) compared the reactions of multiple spring wheat, oat, and barley cultivars to crown rot in glasshouse and field conditions in New South Wales. Similar incidences of disease were recorded for both spring wheat and barley, with genotypic variation being observed within both species. Crown rot symptoms were not observed in any cultivar of oat. An early description by Purss (1969) similarly observed low levels of symptom development in field-grown oat, with disease rarely extending into the culm. Observations in the current study and by Percy et al. (2012) have also indicated very low levels of visual discoloration on oat leaf sheaths. These previous studies, taken together with the low levels of fungal biomass measured in infected oat seedlings in this current study, indicate that oat is a poor host for both of these Fusarium spp. and may serve a useful role as a rotation crop in some wheat-growing environments. This proposition requires further investigation in field trials involving the testing of adult plants and postharvest crop stubble for fungal load.

Crown rot reactions for a range of triticale cultivars have not been published, with the reaction of one reported cultivar being of a similar value to spring wheat cultivars (Klein et al. 1989). The triticale reaction to disease and Fusarium biomass quantities in the current study were similar to the spring and durum wheat reactions and generally greater than the rye reactions; however, some genotypic variation was observed. Rye has also had limited attention given to its reaction to crown rot disease. Höxter et al. (1992) evaluated a range of rye genotypes in glasshouse and field trials in Germany for their "foot rot" reaction to $F$. culmorum and $F$. graminearum. Genetic variance was observed between genotypes for their disease reactions, with a strong correlation between reactions to $F$. culmorum and $F$. graminearum. Rye in the current study showed less visual discoloration than barley, durum wheat, spring wheat, and triticale. A difference in F. pseudograminearum biomass was also recorded between the two rye cultivars, which suggests that further assessment of this species is required to determine whether partial resistance is present. This may act to inform the selection of parents when creating triticale cultivars.

Maize and sorghum are not considered typical hosts for $F$. pseudograminearum or $F$. culmorum, with sorghum being recommended as a useful rotation crop in crown-rot-infested fields (Burgess et al. 1996; Monds et al. 2005). Rice has not previously been assessed for its crown rot reaction to $F$. pseudograminearum or F. culmorum; however, as a major food source worldwide, it lends itself to being 
examined and has potential for further investigation considering its position as an experimental model for functional and evolutionary genomics of cereals (Paterson et al. 2005). These three species produced the lowest visual ratings for disease and the sorghum and maize supported the lowest quantities of detectable pathogen DNA.

Colonization of primary roots has been reported as minor compared with leaf sheath tissues during seedling experiments (Knight and Sutherland 2013). F. culmorum is generally described as causing more disease on the primary roots (Scherm et al. 2013) compared with $F$. pseudograminearum; however, limited comparative investigations have been reported. The comparison of the primary roots of barley, spring wheat, and durum wheat in this study indicated similar levels of colonization by $F$. pseudograminearum and $F$. culmorum (Table 5). The only significant difference between cultivars for $F$. pseudograminearum colonization in roots was observed in Tilga barley, which developed less pathogen biomass than Jandaroi and Livingston (Table 4). Research on root physiology during crown rot disease may prove informative; however, root assessments are unlikely to be useful for routine crown rot disease screening due to the challenges of root extraction from soil and the relatively low levels of root discoloration observed, except in the immediate vicinity of an infected crown or subcrown internode, until the plant is in an advanced stage of the disease (Purss 1969).

This research has presented a qPCR assay for $F$. culmorum and the first direct comparison of $F$. pseudograminearum and $F$. culmorum colonization across a wide selection of potential host species, which has indicated a diverse range of disease responses. Differences in cereal species reactions may reveal potential sources of resistance and inform strategies for crop rotations. Further research is warranted into direct comparisons of multiple isolates of $F$. pseudograminearum and $F$. culmorum for their visual effects and resulting biomass in winter cereals, particularly in field situations. The successful design of $F$. pseudograminearum- and $F$. culmorum-specific qPCR assays allows studies of the interactions between these two pathogens in coinoculation experiments and assessment of the level of competition between them in the field. Comparison of crown rot disease caused by $F$. pseudograminearum and $F$. culmorum is a direction of research which will lead to greater understanding of the potential impacts of these pathogens, particularly in environments where both pathogens are present, and will begin to tease apart the crown rot complex.

\section{Acknowledgments}

This study was funded by the Early Career Researcher Program of the University of Southern Queensland, Australia. We thank S. Pethybridge and D. Shah (Cornell University, NY) and B. MacDonald (Queensland Department of Agriculture and Fisheries, Australia) for statistical guidance.

\section{Literature Cited}

Backhouse, D., Abubakar, A. A., Burgess, L. W., Dennis, J. I., Hollaway, G. J., Wildermuth, G. B., Wallwork, H., and Henry, F. J. 2004. Survey of Fusarium species associated with crown rot of wheat and barley in eastern Australia. Australas. Plant Pathol. 33:255-261.

Backhouse, D., and Burgess, L. W. 2002. Climatic analysis of the distribution of Fusarium graminearum, $F$. pseudograminearum and $F$. culmorum on cereals in Australia. Australas. Plant Pathol. 31:321-327.

Balmas, V. 1994. Root rot of wheat in Italy caused by Fusarium graminearum Group 1. Plant Dis. 78:317.

Bentley, A. R. 2007. Genetic Variation in Field Populations of the Crown Rot Fungus Fusarium pseudograminearum. The University of Sydney, Sydney, NSW, Australia.

Burgess, L. W. 1967. Ecology of Some Fungi Causing Root and Crown Rots of Wheat. The University of Sydney, Sydney, NSW, Australia.

Burgess, L. W., Backhouse, D., Summerell, B. A., and Swan, L. J. 2001. Crown rot of wheat. Pages 271-294 in: Fusarium: Paul E. Nelson Memorial Symposium. B. Summerell, J. Leslie, D. Backhouse, W. Bryden, and L. Burgess, eds. American Phytopathological Society Press, St. Paul, MN.

Burgess, L. W., Backhouse, D., Swan, L. J., and Esdaile, R. J. 1996. Control of Fusarium crown rot of wheat by late stubble burning and rotation with sorghum. Australas. Plant Pathol. 25:229-233.

Burgess, L. W., Wearing, A. H., and Toussoun, T. A. 1975. Surveys of Fusaria associated with crown rot of wheat in eastern Australia. Aust. J. Agric. Res. 26:791-799.

Cassini, R. 1981. Fusarium diseases of wheat and corn in western Europe. Pages 56-63 in: Fusarium: Diseases, Biology, and Taxonomy. P. E. Nelson, T. A.
Toussoun, and R. J. Cook, eds. The Pennsylvania State University Press, University Park.

Cook, R. J. 1968. Fusarium root and foot rot of cereals in the Pacific northwest Phytopathology 58:127-131.

Dodman, R. L., and Reinke, J. R. 1982. A selective medium for determining the population of viable conidia of Cochliobolus sativus in soil. Aust. J. Agric. Res. 33:287-291.

Dyer, A., Johnston, R., Hogg, A., and Johnston, J. 2009. Comparison of pathogenicity of the Fusarium crown rot (FCR) complex (F. culmorum, $F$. pseudograminearum and $F$. graminearum) on hard red spring and durum wheat. Eur. J. Plant Pathol. 125:387-395.

Evans, M. L., Hollaway, G. J., Dennis, J. I., Correll, R., and Wallwork, H. 2010 Crop sequence as a tool for managing populations of Fusarium pseudograminearum and F. culmorum in south-eastern Australia. Australas. Plant Pathol. 39:376-382.

Gargouri, S., Hajlaoui, M. R., Guermech, A., and Marrakchi, M. 2001 Identification des espèces fongiques associées à la pourriture du pied du blé et étude de leur répartition selon les étages bioclimatiques en Tunisie. EPPO Bull. 31:499-503.

Grey, W. E., and Mathre, D. E. 1988. Evaluation of spring barleys for reaction to Fusarium culmorum seedling blight and root rot. Can. J. Plant Sci. 68: 23-30.

Hogg, A. C., Johnston, R. H., and Dyer, A. T. 2007. Applying real-time quantitative PCR to Fusarium crown rot of wheat. Plant Dis. 91:1021-1028.

Hollaway, G. J., Evans, M. L., Wallwork, H., Dyson, C. B., and McKay, A. C. 2013 Yield loss in cereals, caused by Fusarium culmorum and F. pseudograminearum, is related to fungal DNA in soil prior to planting, rainfall, and cereal type. Plant Dis. 97:977-982.

Höxter, H., Sieber, G., Miedaner, T., and Geiger, H. H. 1992. Test systems for evaluating quantitative resistance against Fusarium foot rot in inbred lines of winter rye. Plant Breed. 108:274-282.

Klaasen, J., Matthee, F., Marasas, W., and Van Schalkwyk, D. 1991. Comparative isolation of Fusarium species from plant debris in soil and wheat stubble and crowns at different locations in the southern and western Cape. Phytophylactica 23:299-307.

Klein, T. A., Burgess, L. W., and Ellison, F. W. 1989. The incidence of crown rot in wheat, barley and triticale when sown on two dates. Aust. J. Exp. Agric. 29: 559-563.

Klemsdal, S. S., and Elen, O. 2006. Development of a highly sensitive nested-PCR method using a single closed tube for detection of Fusarium culmorum in cereal samples. Lett. Appl. Microbiol. 42:544-548.

Knight, N. L., Martin, A., Sutherland, M. W., and Herde, D. J. 2012. Assessment of infection by Fusarium pseudograminearum in wheat seedling tissues using quantitative PCR and a visual discoloration scale. Plant Dis. 96:1661-1669.

Knight, N. L., and Sutherland, M. W. 2013. Spread of Fusarium pseudograminearum in wheat seedling tissues from a single inoculation point. Australas. Plant Pathol. 42:609-615.

Leišová, L., Kučera, L., Chrpová, J., Sýkorová, S., Šíp, V., and Ovesná, J. 2006. Quantification of Fusarium culmorum in wheat and barley tissues using realtime PCR in comparison with DON content. J. Phytopathol. 154:603-611.

Li, H. B., Zhou, M. X., and Liu, C. J. 2009. A major QTL conferring crown rot resistance in barley and its association with plant height. Theor. Appl. Genet. 118:903-910.

Liddell, C. M. 1985. The comparative pathogenicity of Fusarium graminearum group 1, Fusarium culmorum and Fusarium crookwellense as crown, foot and root rot pathogens of wheat. Australas. Plant Pathol. 14:29-31.

Malalasekera, R. A. P., and Colhoun, J. 1968. Fusarium diseases of cereals III. Water relations and infection of wheat seedlings by Fusarium culmorum. Trans. Br. Mycol. Soc. 51:711-720.

Malligan, C. D. 2009. Crown rot (Fusarium pseudograminearum) symptom development and pathogen spread in wheat genotypes with varying disease resistance. Ph.D. thesis, University of Southern Queensland, Toowoomba, Australia.

Martin, A., Simpfendorfer, S., Hare, R. A., and Sutherland, M. W. 2013 Introgression of hexaploid sources of crown rot resistance into durum wheat Euphytica 192:463-470.

Mergoum, M., Braun, H. J., Nicol, J., Bagci, A., Ekiz, H., Aktas, H., Dusunceli, F., Cetin, L., Ketata, H., Yahyaoui, A., Bolat, N., and Keser, M. 2000. Screening wheat for root rot disease in WANA region. Page 186 in: Proc. 6th Int. Wheat Congr, Budapest, Hungary.

Mitter, V., Zhang, M. C., Liu, C. J., Ghosh, R., Ghosh, M., and Chakraborty, S 2006. A high-throughput glasshouse bioassay to detect crown rot resistance in wheat germplasm. Plant Pathol. 55:433-441.

Monds, R. D., Cromey, M. G., Lauren, D. R., Menna, M., and Marshall, J. 2005 Fusarium graminearum, $F$. cortaderiae and $F$. pseudograminearum in New Zealand: Molecular phylogenetic analysis, mycotoxin chemotypes and coexistence of species. Mycol. Res. 109:410-420.

Moya-Elizondo, E., Arismendi, N., Castro, M. P., and Doussoulin, H. 2015 Distribution and prevalence of crown rot pathogens affecting wheat crops in southern Chile. Chil. J. Agric. Res. 75:78-84.

Moya-Elizondo, E. A., Rew, L. J., Jacobsen, B. J., Hogg, A. C., and Dyer, A. T. 2011. Distribution and prevalence of Fusarium crown rot and common root rot pathogens of wheat in Montana. Plant Dis. 95:1099-1108. 
Murray, G. M., and Brennan, J. P. 2009a. The Current and Potential Costs from Diseases of Barley in Australia. Grains Research and Development Corporation, Barton, ACT, Australia.

Murray, G. M., and Brennan, J. P. 2009b. The Current and Potential Costs from Diseases of Wheat in Australia. Grains Research and Development Corporation, Barton, ACT, Australia.

Nelson, K. E., and Burgess, L. W. 1994. Reaction of Australian cultivars of oats and barley to infection by Fusarium graminearum group 1. Aust. J. Exp. Agric. 34:655-658

Nelson, K. E., and Burgess, L. W. 1995. Effect of rotation with barley and oats on crown rot of wheat in the northern wheat belt of New South Wales. Aust. J. Exp. Agric. 35:765-770

Nirenberg, H. I. 1976. Untersuchungen über die morphologische Differenzierung in der Fusarium Sektion Liseola. Mitt. Biol. Bundesanst. Land- Forstwirtsch. Berlin-Dahlem 169:1-117.

Paterson, A. H., Freeling, M., and Sasaki, T. 2005. Grains of knowledge: Genomics of model cereals. Genome Res. 15:1643-1650.

Patterson, H. D., and Thompson, R. 1971. Recovery of inter-block information when block sizes are unequal. Biometrika 58:545-554.

Percy, C. D., Wildemuth, G. B., and Sutherland, M. W. 2012. Symptom development proceeds at different rates in susceptible and partially resistant cereal seedlings infected with Fusarium pseudograminearum. Australas. Plant Pathol. 41:621-631.

Petrisko, J. E., and Windes, J. M. 2006. Quantification of Fusarium culmorum in crown rot resistant and susceptible wheat varieties using a tri5 gene-based realtime PCR assay. (Abstr.) Phytopathology 96:S92.

Purss, G. S. 1966. Studies of varietal resistance to crown rot of wheat caused by Fusarium graminearum Schw. Queensl. J. Agric. Anim. Sci. 23:475-498.

Purss, G. S. 1969. The relationship between strains of Fusarium graminearum Schwabe causing crown rot of various gramineous hosts and stalk rot of maize in Queensland. Aust. J. Agric. Res. 20:257-264.

Quazi, S. A. J., Burgess, L. W., and Smith-White, J. 2009. Sorghum is a suitable break crop to minimise Fusarium pseudograminearum in any location regardless of climatic differences, whereas Gibberella zeae is location and climate specific. Australas. Plant Pathol. 38:91-99.

Rossi, V., Cervi, C., Chiusa, G., and Languasco, L. 1995. Fungi associated with foot rots on winter wheat in northwest Italy. J. Phytopathol. 143:115-119.

Rozen, S., and Skaletsky, H. J. 2000. Primer3 on the WWW for general users and for biologist programmers. Pages 365-386 in: Bioinformatics Methods and Protocols: Methods in Molecular Biology. S. Misener and S. A. Krawetz, eds. Humana Press, Totowa, NJ.
Saremi, H., Ammarellou, A., and Jafary, H. 2007. Incidence of crown rot of wheat caused by Fusarium pseudograminearum as a new soil born fungal species in north west Iran. Pak. J. Biol. Sci. 10:3606-3612.

Scherm, B., Balmas, V., Spanu, F., Pani, G., Delogu, G., Pasquali, M., and Migheli, Q. 2013. Fusarium culmorum: Causal agent of foot and root rot and head blight on wheat. Mol. Plant Pathol. 14:323-341.

Schilling, A. G., Möller, E. M., and Geiger, H. H. 1996. Polymerase chain reaction-based assays for species-specific detection of Fusarium culmorum, F. graminearum, and F. avenaceum. Phytopathology 86:515-522.

Scott, J., Akinsanmi, O., Mitter, V., Simpfendorfer, S., Dill-Macky, R., and Chakraborty, S. 2004. Prevalence of Fusarium crown rot pathogens of wheat in southern Queensland and northern New South Wales. In: Proc. 4th Int. Crop Sci. Congr. Brisbane, QLD Australia.

Simmonds, J. H. 1966. Host Index of Plant Diseases in Queensland. Queensland Department of Primary Industries, Brisbane, QLD, Australia.

Simmonds, P. M. 1941. Root rots of cereals. Bot. Rev. 7:308-332.

Smiley, R. W., Gourlie, J. A., Easley, S. A., Patterson, L.-M., and Whittaker, R. G. 2005. Crop damage estimates for crown rot of wheat and barley in the Pacific northwest. Plant Dis. 89:595-604.

Smiley, R. W., Machado, S., Rhinhart, K. E. L., Reardon, C. L., and Wuest, S. B. 2016. Rapid quantification of soilborne pathogen communities in wheat-based long-term field experiments. Plant Dis. 100:1692-1708.

Smiley, R. W., and Patterson, L. 1996. Pathogenic fungi associated with Fusarium foot rot of winter wheat on the semiarid Pacific northwest. Plant Dis. 80: 944-949.

Strausbaugh, C. A., Overturf, K., and Koehn, A. C. 2005. Pathogenicity and realtime PCR detection of Fusarium spp. in wheat and barley roots. Can. J. Plant Pathol. 27:430-438.

Tunali, B., Nicol, J. M., Hodson, D., Uçkun, Z., Büyük, O., Erdurmuş, D., Hekimhan, H., Aktas, H., Akbudak, M. A., and Bağc1, S. A. 2008. Root and crown rot fungi associated with spring, facultative, and winter wheat in Turkey. Plant Dis. 92:1299-1306.

Van Wyk, P., Los, O., Pauer, G., and Marasas, W. 1987. Geographic distribution and pathogenicity of Fusarium species associated with crown rot of wheat in the Orange Free State, South Africa. Phytophylactica 19:271-274.

Wallwork, H., Butt, M., Cheong, J. P. E., and Williams, K. J. 2004. Resistance to crown rot in wheat identified through an improved method for screening adult plants. Australas. Plant Pathol. 33:1-7.

Wildermuth, G. B., and McNamara, R. B. 1994. Testing wheat seedlings for resistance to crown rot caused by Fusarium graminearum Group 1. Plant Dis. 78:949-953 